\title{
Effect of Salinity, Temperature and Carbon Source on the Growth and Development of Sclerotia of Sclerotinia sclerotiorum Isolated from Semi-arid Environment
}

\author{
Mansour T. Abdullah, Nida Y. Ali and Patrice Suleman* \\ Department of Biological Sciences, Kuwait University, Safat, 13060, Kuwait
}

(Received on February 11, 2008; Accepted on November 4, 2008)

\begin{abstract}
Studies were conducted to determine the effects of temperature, solute potential and carbon source on the mycelial growth, sclerotia development, and apothecium production of an isolate of Sclerotinia sclerotiorum. Mycelial growth rate was greatest at $25^{\circ} \mathrm{C}$ on potato dextrose agar (PDA) medium amended with up to $2 \%$ $\mathrm{NaCl}(\psi s \leq 1.91 \mathrm{MPa})$ and thereafter, growth rate declined. The least number of sclerotia were produced at $20^{\circ} \mathrm{C}$ on both PDA and malt extract agar (MEA) amended with $8 \% \mathrm{NaCl}(\psi s=6.62 \mathrm{MPa})$. With increasing temperature and decreasing solute potential the number and size of sclerotia were significantly reduced. The combined effect of temperature, solute potential and carbon source on sclerotia production were highly significant and had an impact on the development of the rind layer cells of sclerotia. These cells lacked a transparent cell wall which was surrounded by a compact melanized layer, and some of these cells appeared to be devoid of cell contents or were totally vacuolated. The survival of the sclerotia with increase in salinity and temperature appeared to affect melanization and the nature of the rind cells. The observations of this study re-enforces the need for an integrated disease management to control $S$. sclerotiorum.
\end{abstract}

Keywords : melanization, salinity, sclerotia, Sclerotinia sclerotiorum, temperature

Sclerotinia sclerotiorum is a soil-borne plant pathogenic fungus that attacks numerous plants at all stages of growth, development and harvested products. Diseases caused by Sclerotinia are commonly known as white mold, sclerotinia wilt or stalk rot. S. sclerotiorum is geographically cosmopolitan and has a broad ecological distribution. It had been originally believed to occur only in cool, moist areas, but was known to occur in hot, dry areas as well (Purdy, 1979). $S$. sclerotiorum is a necrophyte, not a host specific pathogen with a host range mostly of dicotyledons. Approximately $90 \%$ of the life cycle of Sclerotinia species is spent in soil

\footnotetext{
*Corresponding author.

Phone)+965-948-5643, FAX) +965-484-7054

E-mail)suleman@kuc01.kuniv.edu.kw
}

as sclerotia (Adams and Ayers, 1979; Agrios, 1997).

The pathogen over-winters or over-summers mainly as sclerotia which become propagules. Sclerotia are hard structures consisting of an exterior black covering (rind) which is about three layers of cells that acts as a protectant from microorganisms, a layer of two to four cells deep (cortex), and an interior large portion (medulla) of fungal cells (Campbell, 1989; Huang, 1983; Tourneau, 1979).

During the growing season, depending on the inherent nature of the fungus and various environmental factors, the sclerotia can germinate and form either mycelium or ascospores by apothecia which can infect a host (Sun and Yang, 2000). Ascospores are the primary inoculum for epidemics in many crops (Lumsden, 1979; Purdy, 1979; Schwartz and Steadman, 1978).

Huang (1985) reported that myceliogenic germination of sclerotia of $S$. sclerotiorum was associated with the degree of melanization of cell walls of sclerotial rind. A sclerotium with an incomplete melanized rind can germinate myceliogenically and cause infection on seedlings. On the other hand, a completely melanized rind impedes immediate germination of black sclerotia and fosters dormancy (Huang, 1985).

The sclerotia in the soil can remain viable for 3 years and because they do not all germinate or die at the same time the inoculum potential builds up with time and can render an agricultural area less productive (Adams and Ayers, 1979). Although a number of factors such as soil type, previous crop, environmental conditions etc. affect the survival of sclerotia, microbial degradation (or biocontrol) is probably the main reason for the decline in the numbers of sclerotia (Abawi and Grogan, 1979).

On the other hand, carpogenic germination of sclerotia produces apothecium which releases ascospores that are disseminated by air. Under favorable conditions, including adequate moisture, ascospores germinate within 3-6 hours after release (Adams and Ayers, 1979).

Sclerotinia sp. can utilize many organic compounds as carbon source for growth and sclerotium production. Trehalose, sugar alcohols, and organic acids commonly produced and present in the fungus are poor carbon sources (Tourneau, 
1979). Growth and sclerotium formation by S. sclerotiorum occurred only when the inorganic macronutrients including phosphorus, potassium, magnesium, and sulfur were present in the medium and were enhanced by the addition of an inorganic micronutrient mixture. Apparently, numerous sclerotia are formed when the fungus grows on a medium which supports good growth (Purdy and Grogan, 1954).

The fungus is found world-wide and in Kuwait (semiarid conditions) sclerotia were found in agricultural protected areas or in greenhouses where vegetables are grown. In these protected agricultural areas or greenhouse the cool soil temperatures, high humidity and increase in the number of susceptible plants appear to be contributing factors for the disease incidence. The agricultural soils in Kuwait to some extent have become saline through irrigation and experience very hot summer temperatures. The fate of sclerotia that are incorporated into these soils after crop harvest has not been investigated. The objective of this study was to determine the effect of temperature, salinity and carbon source in vitro on the survival, germination and apothecium production by the sclerotia of $S$. sclerotiorum.

\section{Materials and Methods}

Sclerotinia sclerotiorum was isolated from infected stems of eggplants (Solanum melongena), from Rabiya, Kuwait in 2004. Sclerotia were removed and sterilized with 5\% chlorox solution for $30 \mathrm{~s}$ then triple rinsed with double sterile distilled water and left to air dry. The sclerotia were placed in standard Petri-dishes with $20 \mathrm{ml}$ of sterilized PDA (Oxoid, England) and incubated under florescent light at $25^{\circ} \mathrm{C}$. A cultured isolate was stored in vials at $4^{\circ} \mathrm{C}$ for further studies. Growth and colony morphology of $S$. sclerotiorum were studied in 7 day-old cultures grown on PDA. Data on sclerotia formation, size and color were also recorded.

The growth and developmental studies of mycelium and sclerotia. S. sclerotiorum was studied on PDA to determine the effect of salinity, temperature and carbon source on the growth and development of mycelia and sclerotia. Medium size sclerotia (about $3 \mathrm{~mm}$ in diameter) and active mycelium plugs ( $5 \mathrm{~mm}$ in diameter) were used. Each experiment was done twice with three replications and daily observations were recorded as: (1) radial growth of mycelium, (2) number of days for sclerotia initiation, (3) number of sclerotia produced after 10 and 21 days, (4) the diameter of sclerotia produced, (5) weight of sclerotia produced and (6) melanization of sclerotia from white to black.

The effect of salinity on sclerotia and mycelium of $S$. sclerotiorum on PDA. Sclerotia and active mycelium plugs were studied in standard Petri-dishes with $20 \mathrm{ml}$ of PDA medium amended with $\mathrm{NaCl}$ at the following concentrations: $0,1,2,3,4,6,8$, and 10\% [0.37-8.15 MegaPascals $(\mathrm{MPa})]$. The solute potential measured in osmolality using a Wescor Vapor Pressure Osmometer at $22^{\circ} \mathrm{C}$ was converted to $\mathrm{MPa}$ using van't Hoff relation: $\mathrm{MPa}=\mathrm{RTc}$, where $\mathrm{RT}=$ $2.454 \mathrm{~kg} \mathrm{MPa} \mathrm{mol}^{-1}$ at $22^{\circ} \mathrm{C}$ and $\mathrm{c}=$ osmolality in $\mathrm{mol} \mathrm{kg}^{-1}$. Petri-dishes with sclerotia of mycelia were sealed with Para-film, placed in plastic bags and incubated at $25^{\circ} \mathrm{C}$ with constant lighting. Daily observations on growth and development were recorded up to day 11 .

The effect of temperature on the viability of sclerotia and mycelium on PDA. The effect of temperature on the mycelial and sclerotial growth of $S$. sclerotiorum was determined at $25,30,35,40$, and $45^{\circ} \mathrm{C}$ on PDA. Mycelial plugs and sclerotia were placed separately on the PDA. Cultures were sealed as stated earlier and incubated for 7 days at different temperatures. After 7 days exposure to the temperature treatments, the Petri-dishes with mycelial plugs or sclerotia were incubated at room temperature under fluorescent light for 21 days and daily measurements were recorded.

The effect of temperature on the viability of sclerotia on sandy soil. Sclerotia were surface sterilized, air dried, placed on the top surface of sterile sand in ovens at the following temperature: $30,40,50,60$, and $70^{\circ} \mathrm{C}$. After 24 , 48 , and $72 \mathrm{~h}$, sclerotia were removed and placed on PDA at $25^{\circ} \mathrm{C}$ to determine the viability of the sclerotia.

The combined effect of salinity, temperature, and carbon source on the sclerotial development of $\boldsymbol{S}$. sclerotiorum. The viability of sclerotia and active mycelium plugs of $S$. sclerotiorum were studied under the influence of three combined factors, salinity, temperature, and carbon source. For carbon source, PDA and MEA were used in which potato and malt are the source of carbon.. The media were amended with $\mathrm{NaCl}$ at the following concentrations $0,1,2$, $3,4,6$, and $8 \%$. Media with different salt concentrations with either sclerotia or mycelia plugs were incubated at 20, 25,30 , and $35^{\circ} \mathrm{C}$. The study was set up as a factorial design and for each treatment there were four replicates. Daily observations were recorded for 7 days and at room temperature for a total of 21 days study. Daily observations were recorded.

The effect of salinity, temperature and carbon source on apothecium development. Apothecium development from sclerotia was studied in different carbon source, salinity, and temperature. Water agar (WA) and corn meal agar (CMA) were used as a carbon sources. Three replicates with sclerotia were placed in WA amended with concentrations of $\mathrm{NaCl}$ 
at 0.07 and $1.53 \mathrm{MPa}, \mathrm{CMA}$ was at 0.09 and $1.57 \mathrm{MPa}$. Petri-dishes with apotheicia were incubated at 15 , and $20^{\circ} \mathrm{C}$ with constant lightning. All Petri-dishes were sealed as before and sclerotia were checked regularly for apothecium production for 90 days.

Transmission electron microscope (TEM) study of sclerotia development. The development of sclerotia was studied on PDA amended with $0-6 \% \mathrm{NaCl}$ at $25^{\circ} \mathrm{C}$. Also the sclerotia development on amended media and at $35^{\circ} \mathrm{C}$ were compared with a control treatment of sclerotia development on PDA at room temperature. Different stages of sclerotia development (white to black) were removed and processed for microscopy. The samples were fixed overnight $2.5 \%$ gluteraldehyde in $0.1 \mathrm{M}$ sodium cacodylate buffer $(\mathrm{pH} 7.4)$. The fixed samples were washed three times with cacodylate buffer and post-fixed in $1.0 \%$ osmium tetraoxide in the same buffer. After rinsing, the samples were dehydrated in a graded concentration of ethanol and embedded in epon resin. Semi-thin sections were cut and stained with toluidine blue and examined under light microscope. Ultrathin sections were cut using an ultramicrotome (LEICA UtracutUCT) and stained with uranyl acetate followed by lead citrate. The stained sections were examined with a transmission electron microscope (JOEL JEM-1200, EX II). Micrographs were taken at $80 \mathrm{kV}$ on Kodak 4489 ESTAR thickbase EM film.

Statistical analysis. Data on the growth and sclerotia production from salinity tests were analyzed using analysis of variance (ANOVA) and Fisher's Protected Least Significance Difference (LSD) to determine differences between treatments at $95 \%$ confidence level. Also a factorial analysis of variance was used to test the effects of carbon source, temperature and salinity treatments as well the interactions. In order to homogenize variances each value of sclerotia production and growth rate data were transformed to the square root of the value plus $0.5(\sqrt{\mathrm{x}}+0.5)$. The analyses were performed using MSTAT-C statistical package, Michigan State University.

\section{Results}

Cultural characteristics of $\boldsymbol{S}$. sclerotiorum. The mycelium plug of $S$. sclerotiorum showed vigorous growth filling the plate within 3 days at $25^{\circ} \mathrm{C}$. The growth rate was $16 \mathrm{mmd}^{-1}$. Hyphae that initiated the development of sclerotia grew upright above the mycelial mat on the medium. These hyphae developed numerous dichotomous branches and anastamoses ensued (Fig. 1A \& B), when they come in contact with each other producing short protuberances. Some of these short hyphae went through further anasto-

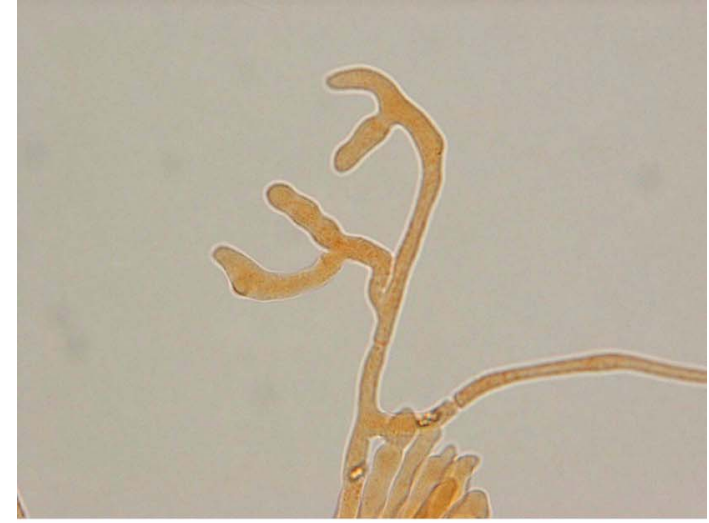

(A)

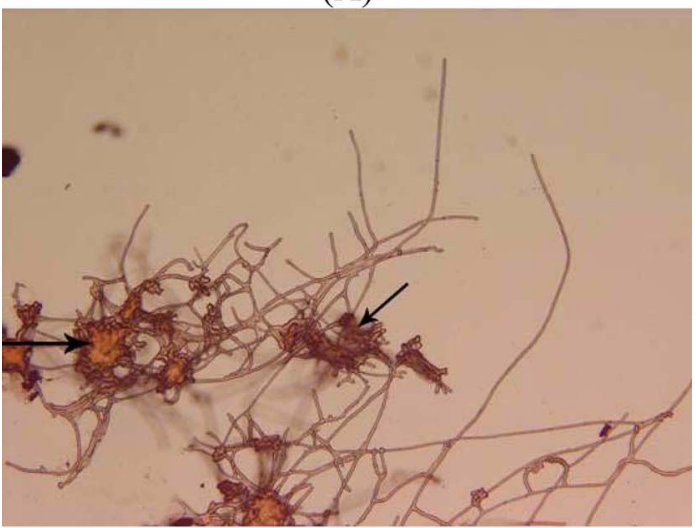

(B)

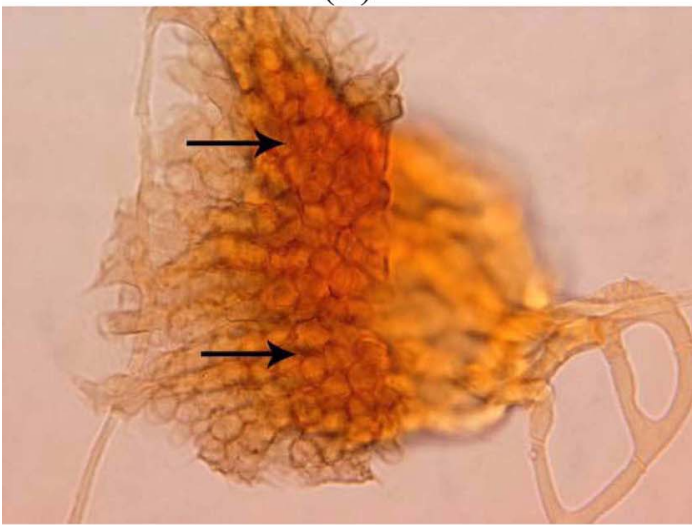

(C)

Fig. 1. Light micrographs of (A) primary hyphae with dichotomous branches which serve as initials for sclerotia development (Bright field microscopy x100). (B) Intermingling of hyphae and the merging of several initials to form sclerotia, arrows (x10). (C) Tuft-like appearance of developing sclerotia as result of hyphal anastomosis and the development of short protuberances as indicated by arrows (Bright field microscopy x100).

moses and cell divisions (Fig. 1C). Eventually, a tuft-like appearance became visible. As the sclerotia developed and matured, the peripheral hyphae develop septa at the tips and the outer most cells become swollen and rounded. These cells became pigmented or melanized starting from the 
outer most wall to the wall underneath the surface wall. Finally the pigment deposited between the cell walls became the rind layer.

Color of sclerotium changed from white to buff after 4 days and turned black on day 6. Average number and size of sclerotia after 10 days were 17 sclerotia and $3.47 \mathrm{~mm}$ in diameter. The average total weight of sclerotia formed was $82 \mathrm{mg} /$ Petri-dish.

The effect of salinity on the viability of sclerotia and mycelium of $\boldsymbol{S}$. sclerotiorum. The mycelial growth rate for sclerotia was fastest or greatest on unamended medium $(0.37 \mathrm{MPa})$ and generally declined with increasing concentration of $\mathrm{NaCl}$ or decreasing solute potential (Table 1). Medium with $8 \% \mathrm{NaCl}(6.62 \mathrm{MPa})$ had the least growth rate $(\leq 1.0 \mathrm{~mm})$ and mycelium growth began 5 days after treatment.

The optimum concentration of $\mathrm{NaCl}$ that produced the highest number of sclerotia was 2\% (1.91 MPa) after which there was a general decline in sclerotia production. PDA with $8 \% \mathrm{NaCl}$ did not produce any sclerotia, and with $10 \%$ $\mathrm{NaCl}$ sclerotia showed no myceliongenic growth after 3 weeks. The largest (diameter) and the heaviest (weight) sclerotia were produced on $1 \% \mathrm{NaCl}(1.09 \mathrm{MPa})$ treatment. Salinity greater than $1 \%$ caused a reduction in the weight of the sclerotia with $6 \% \mathrm{NaCl}$ producing smallest sclerotia. There was a significant difference between $\mathrm{NaCl}$ treatments with respect to number of sclerotia produced and the weight of the sclerotia $(P \leq 0.05)$ (Table 1).

Growth of mycelia on unamended medium had the fastest growth rate $\left(25.7 \mathrm{mmd}^{-1}\right)$ and with decreasing solute potential or increasing concentration of $\mathrm{NaCl}$ the growth rate generally declined. However, medium with $2 \% \mathrm{NaCl}$ produced the highest number of sclerotia (Table 2).

The mycelial growth rate at 3 and $4 \% \mathrm{NaCl}$ were statistically the same $(P \leq 0.05)$ but there was a significant difference between the numbers of sclerotia produced. Unamended medium produced black sclerotia in 8 days, while the $4-6 \% \mathrm{NaCl}$ amended medium produced black sclerotia after 6 days.

The effect of temperature on the viability of sclerotia and mycelium on PDA. There was a significant decline in germination and growth rate of sclerotia that were exposed to various temperature treatments. The optimum mycelial growth, the heaviest and largest sclerotia were observed at

Table 1. The effect of salinity on the production of sclerotia from germination of sclerotia

\begin{tabular}{cccccc}
\hline \hline $\begin{array}{c}\text { NaCl Concentration } \\
(\%)\end{array}$ & $\begin{array}{c}\psi_{\mathrm{s}} \\
(\mathrm{MPa})\end{array}$ & $\begin{array}{c}\text { No. of sclerotia } \\
(11 \mathrm{~d})\end{array}$ & $\begin{array}{c}\text { Diameter of sclerotia } \\
(\mathrm{mm})\end{array}$ & $\begin{array}{c}\text { Weight of 10 random } \\
\text { sclerotia }(\mathrm{mg})\end{array}$ & $\begin{array}{c}\text { Growth rate } \\
\left(\mathrm{mmd}^{-1}\right)\end{array}$ \\
\hline 0 & 0.37 & $19 \mathrm{c}^{\mathrm{b}}$ & $2.80 \mathrm{a}$ & $70.0 \mathrm{~b}$ & $21.6 \mathrm{a}$ \\
1 & 1.09 & $14 \mathrm{~d}$ & $3.05 \mathrm{a}$ & $80.0 \mathrm{a}$ & $17.6 \mathrm{~b}$ \\
2 & 1.91 & $44 \mathrm{a}$ & $2.40 \mathrm{~b}$ & $60.0 \mathrm{c}$ & $13.3 \mathrm{c}$ \\
3 & 2.59 & $24 \mathrm{~b}$ & $2.55 \mathrm{~b}$ & $55.0 \mathrm{~d}$ & $8.8 \mathrm{~d}$ \\
4 & 3.28 & $12 \mathrm{~d}$ & $2.90 \mathrm{a}$ & $40.0 \mathrm{f}$ & $2.6 \mathrm{e}$ \\
6 & 4.52 & $8 \mathrm{e}$ & $2.17 \mathrm{~b}$ & $50.0 \mathrm{e}$ & $1.3 \mathrm{e}$ \\
8 & 6.62 & $0 \mathrm{f}$ & $0.0 \mathrm{c}$ & $0.0 \mathrm{~g}$ & $1.0 \mathrm{e}$ \\
10 & 8.15 & $0 \mathrm{c}$ & $0.0 \mathrm{c}$ & $0.0 \mathrm{~g}$ & $0.0 \mathrm{e}$ \\
\hline
\end{tabular}

${ }^{a}$ Data for all parameters were transformed by square root plus 0.5 for analysis and then back transformed for presentation.

${ }^{b}$ Means followed by the same letter are not significantly different at $P \leq 0.05$ according to Fisher's Protected Least Significant Difference (LSD).

Table 2. The effect of salinity on the production of sclerotia from germination of mycelial plugs

\begin{tabular}{cccccc}
\hline \hline $\begin{array}{c}\text { NaCl Concentration } \\
(\%)\end{array}$ & $\begin{array}{c}\Psi_{\mathrm{s}} \\
(-\mathrm{MPa})\end{array}$ & $\begin{array}{c}\text { No. of sclerotia }{ }^{\mathrm{a}} \\
(11 \mathrm{~d})\end{array}$ & $\begin{array}{c}\text { Diameter of sclerotia } \\
(\mathrm{mm})\end{array}$ & $\begin{array}{c}\text { Weight of 10 sclerotia } \\
(\mathrm{mg})\end{array}$ & $\begin{array}{c}\text { Growth rate } \\
\left(\mathrm{mmd}^{-1}\right)\end{array}$ \\
\hline 0 & 0.37 & $12 \mathrm{c}^{\mathrm{b}}$ & $3.17 \mathrm{a}$ & $75 \mathrm{a}$ & $25.7 \mathrm{a}$ \\
1 & 1.09 & $17 \mathrm{~b}$ & $3.01 \mathrm{a}$ & $70 \mathrm{~b}$ & $21.1 \mathrm{a}$ \\
2 & 1.91 & $28 \mathrm{a}$ & $2.70 \mathrm{a}$ & $55 \mathrm{~d}$ & $18.2 \mathrm{~b}$ \\
3 & 2.59 & $15 \mathrm{~b}$ & $2.46 \mathrm{~b}$ & $60 \mathrm{c}$ & $15.1 \mathrm{c}$ \\
4 & 3.28 & $10 \mathrm{~cd}$ & $2.80 \mathrm{a}$ & $18 \mathrm{f}$ & $15.3 \mathrm{c}$ \\
6 & 4.52 & $8 \mathrm{~d}$ & $3.00 \mathrm{a}$ & $26 \mathrm{e}$ & $3.0 \mathrm{~d}$ \\
8 & 6.62 & $0 \mathrm{e}$ & $0.0 \mathrm{c}$ & $0 \mathrm{~g}$ & $1.0 \mathrm{de}$ \\
10 & 8.15 & $0 \mathrm{e}$ & $0.0 \mathrm{c}$ & $0 \mathrm{~g}$ & $0.0 \mathrm{e}$ \\
\hline
\end{tabular}

${ }^{a}$ Data for all parameters were transformed by square root plus 0.5 for analysis and then back transformed for presentation.

${ }^{\mathrm{b}}$ Means followed by the same letter are not significantly different at $P \leq 0.05$ according to Fisher's Protected Least Significant Difference (LSD) 
Table 3. The effect of temperature on the viability of sclerotia on sandy soil after $72 \mathrm{~h}$

\begin{tabular}{ccc}
\hline \hline $\begin{array}{c}\text { Temperature } \\
\left({ }^{\circ} \mathrm{C}\right)\end{array}$ & $\begin{array}{c}\text { Sclerotia Viability } \\
(\%)\end{array}$ & $\begin{array}{c}\text { Myceliogenic germination } \\
\text { (\# of days) }\end{array}$ \\
\hline 30 & 100 & 4 \\
40 & 100 & 4 \\
50 & 62.5 & 5 \\
60 & 50.0 & 6 \\
70 & 25.0 & 9 \\
\hline
\end{tabular}

$25^{\circ} \mathrm{C}$. At 30 and $35^{\circ} \mathrm{C}$ the sclerotia did not grow after 7 days. However, when these sclerotia were incubated at $25^{\circ} \mathrm{C}$ normal myceliogenic growth resumed. After 21 days, the inoculated sclerotia incubated at $30^{\circ} \mathrm{C}$ produced the highest number of sclerotia, although this was not statistically different from those produced at 25 and $35^{\circ} \mathrm{C}$ treatments (data not shown). Sclerotia that were exposed to 40 and $45^{\circ} \mathrm{C}$ failed to grow after 21 days at $25^{\circ} \mathrm{C}$.

The mycelium plugs that were incubated at $25^{\circ} \mathrm{C}$ had the highest growth rate which was about twice that of $30^{\circ} \mathrm{C}$. The mycelium plugs that were exposed to 35,40 , and $45^{\circ} \mathrm{C}$ failed to grow even when incubated at room temperature. The diameter and weight of sclerotia produced were almost the same at 25 and $30^{\circ} \mathrm{C}$.

The effect of temperature on the viability of sclerotia on sandy soil. The viability of sclerotia incubated on sand for $72 \mathrm{~h}$ generally declined with increase in temperature (Table 3). The most viable sclerotia were at 30 and $40^{\circ} \mathrm{C}$. The number of days it took sclerotia to germinate after $30^{\circ} \mathrm{C}$ exposure for $72 \mathrm{~h}$ was 4 days compared with 9 days at $70^{\circ} \mathrm{C}$. Similar results were obtained with sclerotia exposed to the same temperatures after 24 and $48 \mathrm{~h}$.

The combined effect of salinity, temperature, and carbon source on the sclerotial development of $\boldsymbol{S}$. sclerotiorum. The effects of carbon source, temperature and salinity on the production of sclerotia were highly significant $(P \leq 0.01)$. Similarly, the interaction between carbon source, temperature and salinity or any of these two factors significantly influenced the production of sclerotia (Table 4). The maximum growth rates of $S$. sclerotiorum on carbon source, temperature, and salinity was 22.6 and $21.3 \mathrm{mmd}^{-1}$ at 0 and $1 \% \mathrm{NaCl}$ concentrations respectively, on $\mathrm{PDA}$ at $25^{\circ} \mathrm{C}$. The least growth and sclerotia production were on both media at $8 \% \mathrm{NaCl}$ at all temperatures. The maximum number of sclerotia was produced on MEA amended with $1-6 \% \mathrm{NaCl}$ at $20^{\circ} \mathrm{C}$ (Table 5).

The effect of salinity, temperature and carbon source on apothecium development. The development of apothe-
Table 4. Analysis of variance of transformed data of the effect of carbon source, temperature and salinity as a factorial treatment on the sclerotial development by $S$. sclerotiorum

\begin{tabular}{|c|c|c|c|c|}
\hline \multicolumn{2}{|l|}{ Effect } & $\begin{array}{c}\text { No. of } \\
\text { sclerotia }^{\text {a }}\end{array}$ & $\begin{array}{c}\text { Diameter of } \\
\text { sclerotia }(\mathrm{mm})\end{array}$ & $\begin{array}{l}\text { Growth rate } \\
\left(\mathrm{mmd}^{-1}\right)\end{array}$ \\
\hline \multicolumn{5}{|c|}{ Carbon source } \\
\hline \multicolumn{2}{|l|}{ PDA } & $12.31 b^{b}$ & $3.13 \mathrm{a}$ & $7.87 \mathrm{a}$ \\
\hline \multicolumn{2}{|l|}{ MEA } & $20.44 \mathrm{a}$ & $3.32 \mathrm{a}$ & $6.91 b$ \\
\hline \multicolumn{5}{|c|}{ Temperature $\left({ }^{\circ} \mathrm{C}\right)$} \\
\hline \multicolumn{2}{|l|}{20} & $22.10 \mathrm{a}$ & $3.56 \mathrm{a}$ & $9.47 \mathrm{~b}$ \\
\hline \multicolumn{2}{|l|}{25} & $21.84 \mathrm{a}$ & $3.36 \mathrm{a}$ & $12.14 \mathrm{a}$ \\
\hline \multicolumn{2}{|l|}{30} & $7.81 \mathrm{~b}$ & $2.79 b$ & $2.52 \mathrm{c}$ \\
\hline \multicolumn{2}{|l|}{0} & $11.83 \mathrm{c}$ & $3.83 \mathrm{a}$ & $12.42 \mathrm{a}$ \\
\hline \multicolumn{2}{|l|}{1} & $25.30 \mathrm{a}$ & $3.93 \mathrm{a}$ & $12.75 \mathrm{a}$ \\
\hline \multicolumn{2}{|l|}{2} & $21.50 \mathrm{ab}$ & $3.70 \mathrm{a}$ & $11.66 \mathrm{a}$ \\
\hline \multicolumn{2}{|l|}{3} & $22.79 \mathrm{ab}$ & $3.78 \mathrm{a}$ & $10.16 \mathrm{ab}$ \\
\hline \multicolumn{2}{|l|}{4} & $19.35 b$ & $3.50 \mathrm{~b}$ & $7.63 b$ \\
\hline \multicolumn{2}{|l|}{6} & $18.76 \mathrm{~b}$ & $3.35 b$ & $2.43 \mathrm{c}$ \\
\hline \multicolumn{2}{|l|}{8} & $2.31 \mathrm{~d}$ & $1.16 \mathrm{c}$ & $0.99 \mathrm{~d}$ \\
\hline \multicolumn{5}{|c|}{ Analysis of variance (ANOVA transformed data) } \\
\hline Source & df & $\begin{array}{l}\text { No. of } \\
\text { sclerotia } \\
F \text { value }\end{array}$ & $\begin{array}{l}\text { Sclerotia } \\
\text { diameter } F \\
\quad \text { value }\end{array}$ & $\begin{array}{l}\text { Growth } \\
\text { rate } \\
F \text { value }\end{array}$ \\
\hline Carbon (C) & 1 & $88.53 * * * \mathrm{c}$ & $2.05 \mathrm{NS}$ & $5.05^{*}$ \\
\hline Temp. $(\mathrm{T})$ & 2 & $154.16^{* * *}$ & $11.58^{* *}$ & $216.39 * * *$ \\
\hline $\mathrm{C} \times \mathrm{T}$ & 2 & $26.59 * * *$ & $2.50 \mathrm{NS}$ & $0.3289 \mathrm{NS}$ \\
\hline Salinity (S) & 6 & $72.23 * * *$ & $46.70 * * *$ & $99.18 * * *$ \\
\hline $\mathrm{C} \times \mathrm{S}$ & 6 & $5.24 * *$ & $10.47 * * *$ & $2.77 *$ \\
\hline $\mathrm{T} \times \mathrm{S}$ & 12 & $3.64 * *$ & $1.76 \mathrm{NS}$ & $10.60 * * *$ \\
\hline $\mathrm{C} \times \mathrm{T} \times \mathrm{S}$ & 12 & $6.71^{* *}$ & $2.72 *$ & $1.44 \mathrm{NS}$ \\
\hline
\end{tabular}

${ }^{a}$ Data for all parameters were transformed by square root plus 0.5 for analysis and then back transformed for presentation.

${ }^{\mathrm{b}}$ Means followed by the same letter are not significantly different at $P \leq 0.05$ according to Fisher's Protected Least Significant Difference (LSD).

${ }^{*} *, * *, * * *=F$ value for effect significant at $P=0.05,0.01, P<0.001$, $\mathrm{NS}=$ Not Significant at 0.05

cium from sclerotia occurred on both water agar (WA, 0.07 $\mathrm{MPa}$ ) and corn meal agar (CMA, $0.09 \mathrm{MPa})$ at 15 and $20^{\circ} \mathrm{C}$. The maximum apothecium $(72.2 \%)$ produced was on CMA at $0.09 \mathrm{MPa}$ incubated at $15^{\circ} \mathrm{C}$. Decrease in solute potential and increase in temperature reduced the number of apothecium produced on both media (Table 6). Multiple apothecia were also produced on sclerotia on CMA at 0.09 $\mathrm{MPa}$ and at 15 and $20^{\circ} \mathrm{C}$.

Transmission electron microscope (TEM) study of sclerotia development. Developmentally, the formation of sclerotia occurred in three phases, which were not mutually exclusive of each other. The first phase is the initiation stage, in which dichotomous highly branched hyphae aggregate, followed by anastomosis to form tufts and discrete 
Table 5. Effect of salinity, temperature and carbon source on the sclerotial development of S. sclerotiorum

\begin{tabular}{|c|c|c|c|c|c|c|}
\hline $\begin{array}{l}\text { Temp } \\
\left({ }^{\circ} \mathrm{C}\right)\end{array}$ & $\begin{array}{c}\mathrm{NaCl} \\
\text { Concentration } \\
(\%)\end{array}$ & $\begin{array}{l}\text { Carbon } \\
\text { Source }\end{array}$ & $\begin{array}{l}\text { No. of sclerotia } \\
\text { (21 d) }\end{array}$ & $\begin{array}{c}\text { Diameter } \\
\text { of sclerotia } \\
(\mathrm{mm})\end{array}$ & $\begin{array}{l}\text { Total wt of } \\
\text { sclerotia /plate } \\
\text { (mg) }\end{array}$ & $\begin{array}{l}\text { Growth rate } \\
\left(\mathrm{mmd}^{-1}\right)\end{array}$ \\
\hline \multirow{14}{*}{20} & 0 & \multirow{7}{*}{ PDA } & 10.00 & 3.64 & 306 & 18.3 \\
\hline & 1 & & 22.50 & 3.77 & 314 & 21 \\
\hline & 2 & & 21.50 & 3.47 & 350 & 17.6 \\
\hline & 3 & & 18.75 & 4.37 & 316 & 14.3 \\
\hline & 4 & & 17.25 & 3.41 & 272 & 8.6 \\
\hline & 6 & & 16.50 & 3.27 & 209 & 1.6 \\
\hline & 8 & & 0.0 & 0.0 & 0 & 0.6 \\
\hline & 0 & \multirow{7}{*}{ MEA } & 21.00 & 4.42 & 623 & 17.3 \\
\hline & 1 & & 42.50 & 3.52 & 544 & 19 \\
\hline & 2 & & 40.50 & 3.28 & 565 & 16.3 \\
\hline & 3 & & 42.00 & 2.94 & 520 & 11.6 \\
\hline & 4 & & 43.75 & 3.64 & 484 & 5.6 \\
\hline & 6 & & 43.50 & 2.96 & 404 & 3.6 \\
\hline & 8 & & 5.50 & 2.76 & 60 & 1.3 \\
\hline \multirow{14}{*}{25} & 0 & \multirow{7}{*}{ PDA } & 15.50 & 3.33 & 307 & 22.6 \\
\hline & 1 & & 22.00 & 3.61 & 377 & 21.3 \\
\hline & 2 & & 23.25 & 3.45 & 345 & 21.0 \\
\hline & 3 & & 26.75 & 3.48 & 425 & 17.3 \\
\hline & 4 & & 16.75 & 3.28 & 192 & 17.0 \\
\hline & 6 & & 28.50 & 3.03 & 215 & 4.0 \\
\hline & 8 & & 0.0 & 0.0 & 0 & 1 \\
\hline & 0 & \multirow{7}{*}{ MEA } & 22.75 & 3.12 & 525 & 19.3 \\
\hline & 1 & & 32.75 & 3.30 & 597 & 17.6 \\
\hline & 2 & & 37.75 & 3.25 & 553 & 18.0 \\
\hline & 3 & & 39.50 & 2.87 & 570 & 17.0 \\
\hline & 4 & & 38.00 & 3.40 & 448 & 11.6 \\
\hline & 6 & & 14.75 & 2.92 & 144 & 3.6 \\
\hline & 8 & & 12.00 & 2.26 & 38 & 1.6 \\
\hline \multirow{14}{*}{30} & 0 & \multirow{7}{*}{ PDA } & 4.50 & 3.06 & 114 & 6.0 \\
\hline & 1 & & 7.00 & 3.47 & 119 & 3.6 \\
\hline & 2 & & 12.75 & 3.21 & 233 & 3.0 \\
\hline & 3 & & 9.50 & 3.33 & 165 & 4.0 \\
\hline & 4 & & 8.50 & 3.07 & 108 & 3.3 \\
\hline & 6 & & 11.85 & 2.31 & 159 & 1.3 \\
\hline & 8 & & 1.00 & 0.0 & 0 & 0.6 \\
\hline & 0 & \multirow{7}{*}{ MEA } & 3.00 & 2.70 & 85 & 0.6 \\
\hline & 1 & & 35.75 & 3.15 & 333 & 2.6 \\
\hline & 2 & & 5.00 & 2.83 & 67 & 4.0 \\
\hline & 3 & & 9.75 & 2.80 & 87 & 3.3 \\
\hline & 4 & & 6.25 & 2.32 & 70 & 3.3 \\
\hline & 6 & & 9.25 & 2.83 & 115 & 1.0 \\
\hline & 8 & & 0.0 & 0.0 & 0 & 0.5 \\
\hline
\end{tabular}

initials with no defined rind layer but only a medulla. These tufts appeared whitish. The second phase, was the development and differentiation stage. At this stage the sclerotia developed in to a spherical bodies and the rind appeared as a separate layer from the medulla. The cortex may or may not be discernable at this stage. The sclerotia was buff to 
Table 6. Effect of salinity, temperature and carbon source on apothecium development after 90 days

\begin{tabular}{lccrcc}
\hline \hline Medium & $\begin{array}{c}\psi_{\mathrm{s}} \\
(-\mathrm{MPa})\end{array}$ & $\begin{array}{c}\text { Temp } \\
\left({ }^{\circ} \mathrm{C}\right)\end{array}$ & $\begin{array}{c}\text { Germination } \\
(\%)\end{array}$ & $\begin{array}{c}\text { Apothecium } \\
\text { Division } \\
\text { Single } \\
(\%)\end{array}$ & $\begin{array}{c}\text { Apothecium } \\
\text { Division } \\
\text { multiple } \\
(\%)\end{array}$ \\
\hline WA & 0.07 & & 55.5 & 5.5 & 0.0 \\
WA & 1.53 & \multirow{2}{*}{15} & 0.0 & 0.0 & 0.0 \\
CMA & 0.09 & & 72.2 & 66.6 & 5.5 \\
CMA & 1.57 & & 0.0 & 0.0 & 0.0 \\
\hline WA & 0.07 & & 55.5 & 38.8 & 0.0 \\
WA & 1.53 & & 0.0 & 0.0 & 0.0 \\
CMA & 0.09 & 20 & 50.0 & 44.4 & 11.1 \\
CMA & 1.57 & & 0.0 & 0.0 & 0.0 \\
\hline
\end{tabular}

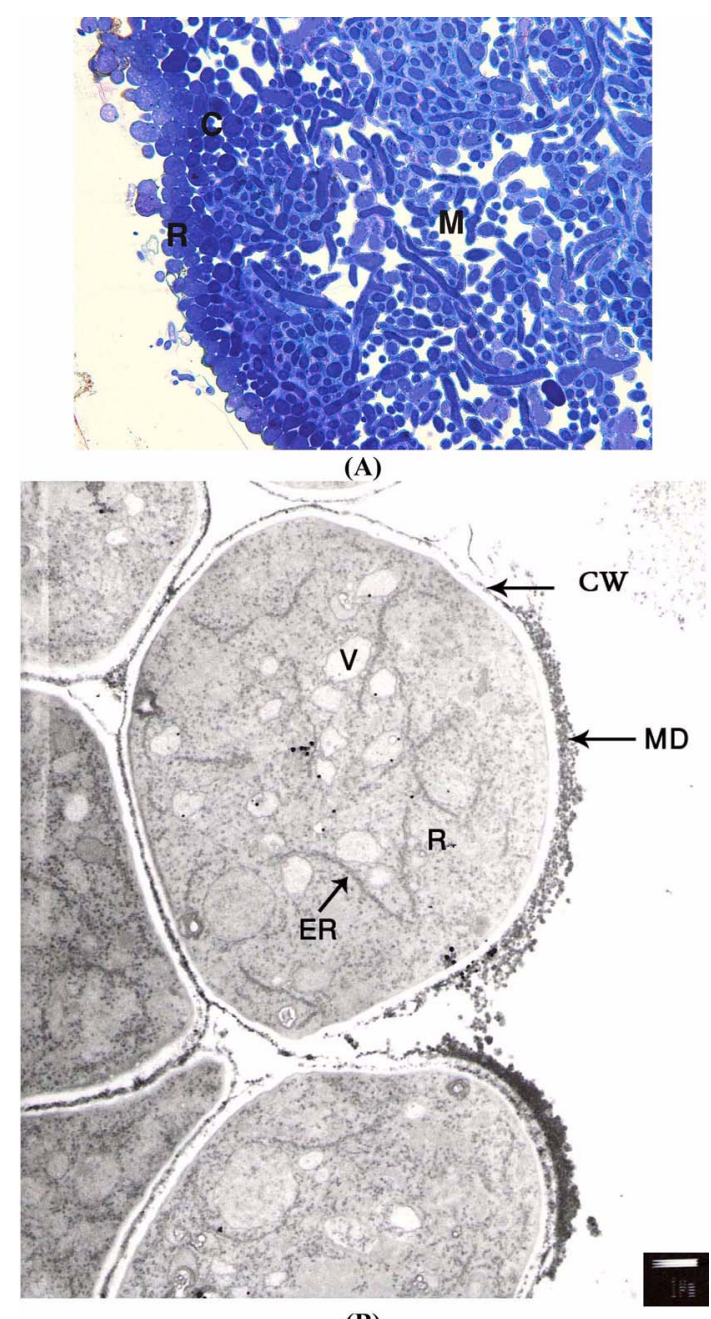

(B)

Fig. 2. Control study of buff to brown sclerotia of S. sclerotiorum: (A) Light micrograph of a section of brown sclerotium showing the rind $(\mathrm{R})$, cortex $(\mathrm{C})$ and medulla $(\mathrm{M})$ layers (bright field microscopy $\mathrm{x} 40$ ), (B) Electron micrograph of brown sclerotium showing melanin deposition on the cell wall (MD), transparent cell wall $(\mathrm{CW})$ vacuoles $(\mathrm{V})$, endoplasmic reticulum (ER), mitochondrium (M), and ribosomes (R). Scale bar $=1 \mu \mathrm{m}$

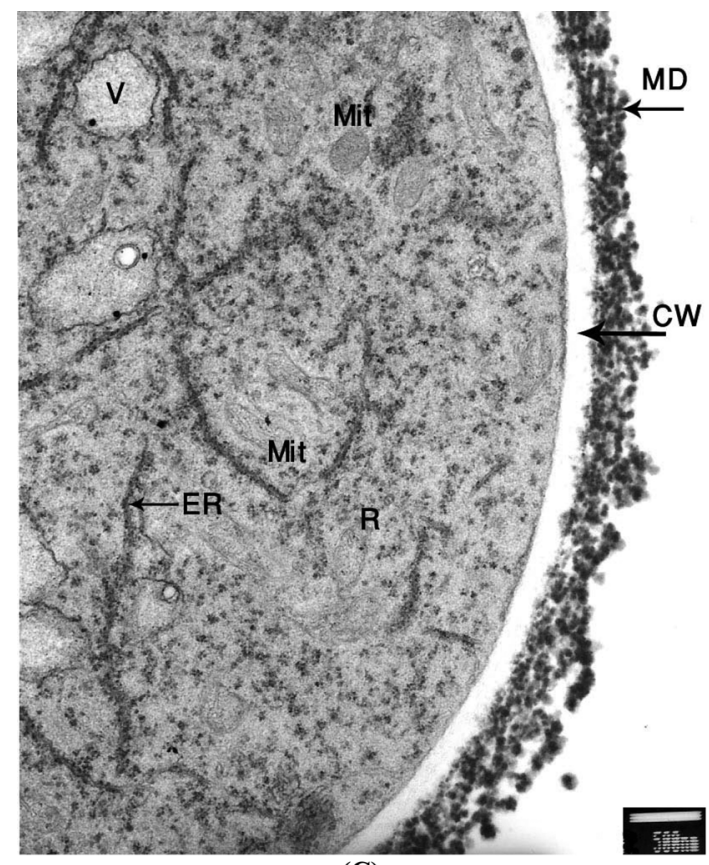

(C)

Fig. 3. Electron micrograph of a section of rind cell of buff to brown sclerotium showing melanin deposition on the cell wall (MD), transparent cell wall (CW), vacuoles (V), endoplasmic reticulum (ER), mitochondria (Mit), and ribosomes (R). Scale bar $=500 \mathrm{~nm}$.

brown in color (Fig. 2). The third was the stage of maturation. The cells of the rind, cortex, and medulla became distinct followed by changes in cell contents and melanization of the rind cells (Fig. $3 \& 4$ ).

Regardless of the treatment with temperature or salinity the development of sclerotia was in these stages. However, sclerotia from medium amended with $4 \% \mathrm{NaCl}(3.28 \mathrm{MPa})$ or greater developed more rapidly and matured in 6 days instead of 8 days. Similarly, higher temperature enhanced the rapid maturation of sclerotia. The differences in the sclerotia development between control and treatments were manifested in the rind layer of cells. First, the rind cell walls in $\mathrm{NaCl}$ treatments did not have transparent cell wall as seen in Fig. $3 \& 4$. Second, the rind cells in salinity treatments appeared devoid of cell contents or seemed to be totally vacuolated compared to those of the control treatment (Fig. 4B \& 6). Third, the rind cells of the amended medium that were not empty had fewer vacuoles (Fig. 6). The control treatment had small and numerous vacuoles (Fig. 4B). Fourth, the melanized layer of the amended medium was a very compact black layer (Fig. 6) while the control showed a loose layer of melanized particles (Fig. 4B).

\section{Discussion}

The development of sclerotia, a hard and compact mass of 


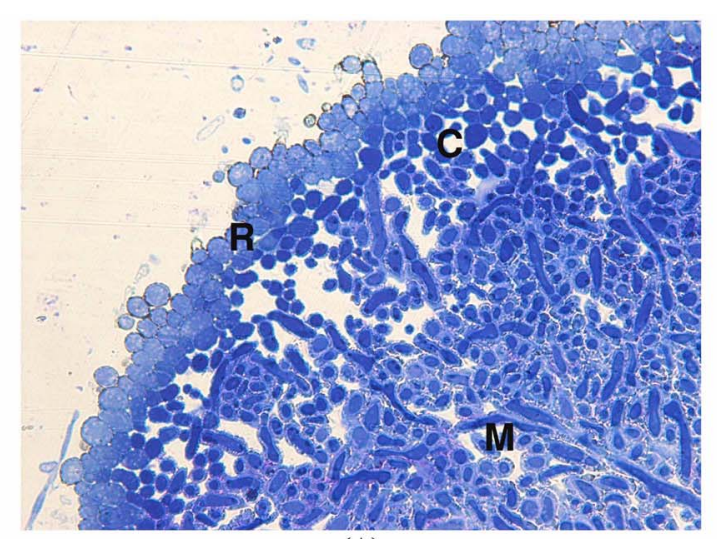

(A)

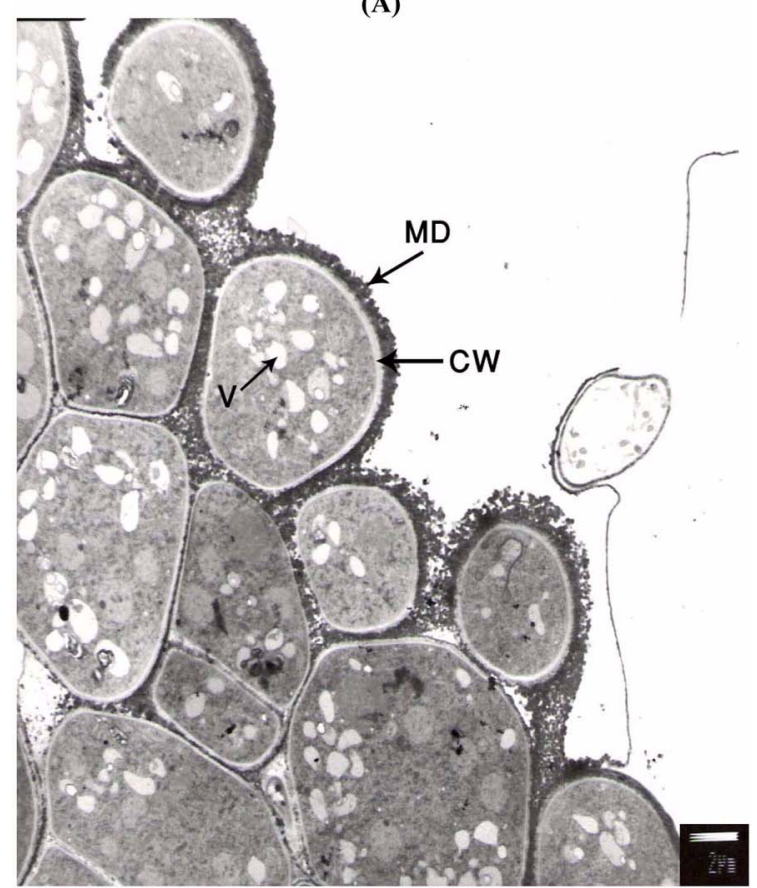

(B)

Fig. 4. Control study of black sclerotium of S. sclerotiorum. (A) Light micrograph of a section of black sclerotium showing the rind (R), cortex (C) and medulla (M) layers (bright field microscopy x40), (B) Electron micrograph of black sclerotium of the developing rind layer showing melanin deposition on the cell wall (MD), transparent cell wall (CW), and vacuoles (V). Scale bar $=2 \mu \mathrm{m}$.

hyphae that are resistant to unfavorable conditions, is of paramount importance to the existence of some fungi. Sclerotia produced by $S$. sclerotiorum cultured at $25^{\circ} \mathrm{C}$ on PDA in this study had three layers; the rind, the cortex and medulla (Fig. 3A \& 4A). The developmental sequence of sclerotia was in three stages: (1) initiation, leading to the formation of sclerotial initials, (2) development, leading to fully grown sclerotia and (3) maturation, resulting into compact mass of hyphae surrounded by a melanized rind layer. Willetts and Wong (1971) reported the sclerotial formation in a similar manner. However, with increase in

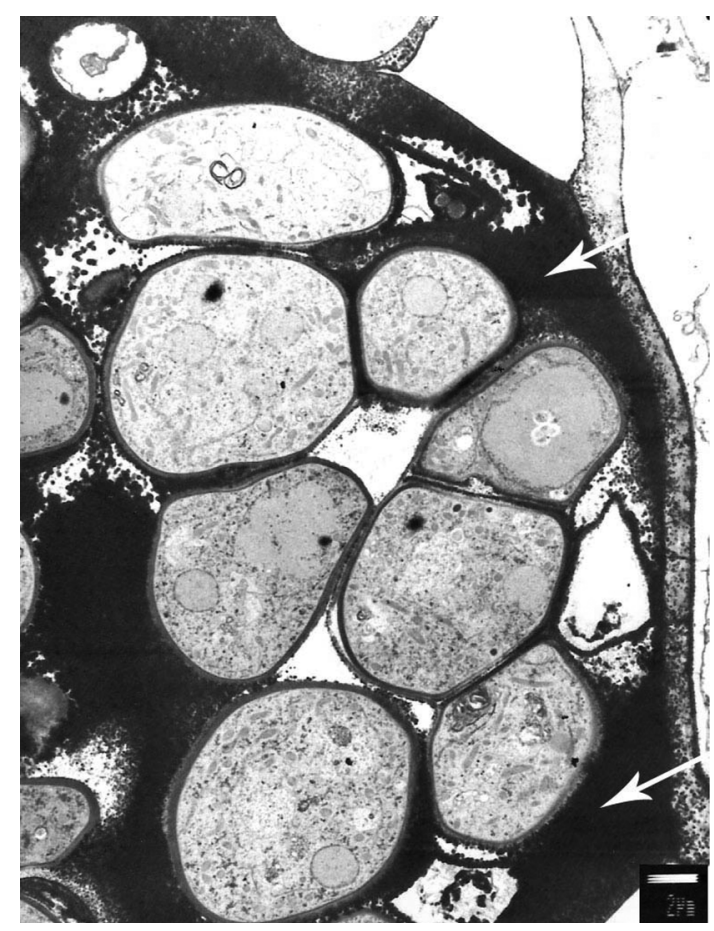

Fig. 5. A section of a sclerotium on $6 \% \mathrm{NaCl}$ : Electron micrograph showing a section of cells of the rind layer with melanin deposits. Scale bar $=2 \mu \mathrm{m}$.

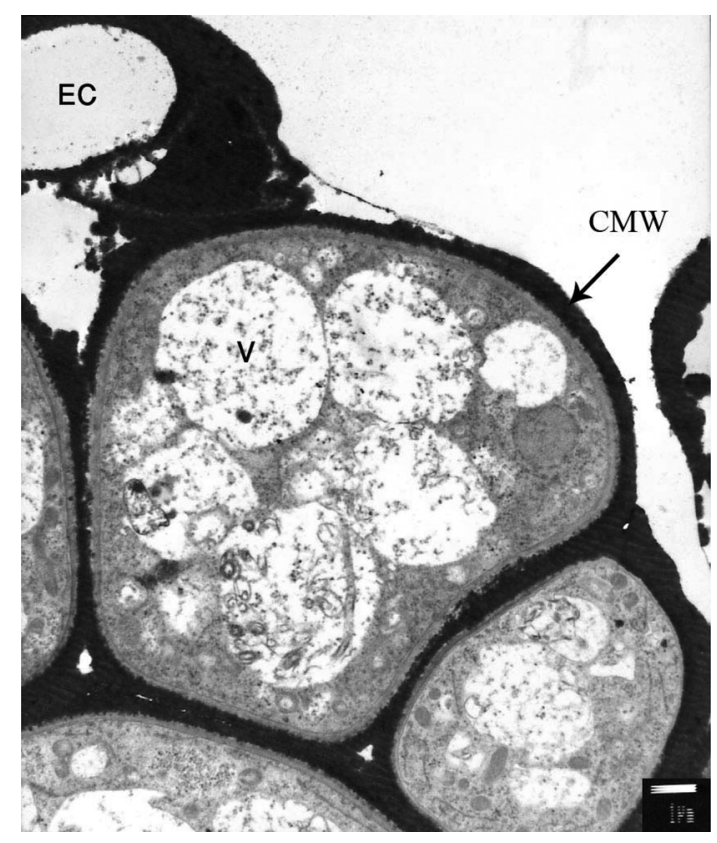

Fig. 6. Electron micrograph of the outer rind cells of a black sclerotium produced on $6 \% \mathrm{NaCl}$ showing compact melanized wall (CMW), empty cell or without cell contents (EC), and large vacuoles (V). Scale bar $=2 \mu \mathrm{m}$.

temperature and decrease in solute potential we observed the following: (1) rapid maturation of sclerotia, (2) size of the sclerotia decreased, (3) the number of sclerotia produ- 
ced decreased and (4) the rind layer developed cells with more compact melanized walls.

Under in vitro conditions, sclerotia failed to germinate or grow at $30-35^{\circ} \mathrm{C}$ for a period of 7 days. However, when incubated at $25^{\circ} \mathrm{C}$, normal myceliogenic growth resumed. Similarly, Hao et al. (2003) found that sclerotia of $S$. sclerotiorum could not grow at $30^{\circ} \mathrm{C}$. Also, the in vitro study showed that the sclerotia were not viable at $40^{\circ} \mathrm{C}$ and above since no visible myceliogenic growth occurred with the same sclerotia when incubated at $25^{\circ} \mathrm{C}$. It is possible that these sclerotia became highly dormant or quiescent and that some other factors such as water or scarification may be necessary to make them germinate if they were still viable. On dry desert sand the viability declined within $72 \mathrm{~h}$ exposure to $50-70^{\circ} \mathrm{C}$. It is also apparent that exposure of sclerotia to $30-40^{\circ} \mathrm{C}$ for 3 days induced the early myceliogenic germination of sclerotia. Higher temperatures could have caused cracks or fissures allowing inner cell growth. The practical implication of the reduction in sclerotia viability with increasing temperature is worth considering if solarization is to be undertaken as a method of control of $S$. sclerotiorum to reduce sclerotia as a source of myceliogenic infection. It is suggested that for solarization the soil should be kept dry and the soil temperature should exceed $40^{\circ} \mathrm{C}$ for 7 days or more. The effect of temperature on the long-term survival of $S$. sclerotiorum is mediated through viable sclerotia since some sclerotia were still viable at $70^{\circ} \mathrm{C}$ for $72 \mathrm{~h}$, while the mycelium died at $40^{\circ} \mathrm{C}$. Thus, solarization of the soils could be considered as part of the disease management program.

In vitro, the salinity study showed that $2-3 \% \mathrm{NaCl}(1.91$ $2.59 \mathrm{MPa}$ ) slowed the growth rate of $S$. sclerotiorum but induced the production of sclerotia significantly. However, at $8 \% \mathrm{NaCl}$ or $6.62 \mathrm{MPa}$, mycelial growth as well as sclerotia development were inhibited but myceliogenic growth occurred over a range of $0-6 \% \mathrm{NaCl}$ or $0.37-4.52$ $\mathrm{MPa}$. Abawi and Grogan (1975), reported similar tolerance levels ( -1.0 to -64 bars) of solute potential for the growth and sclerotia production. Also similar values caused a reduction in growth of Macrophomina phaseolina (CervantesGarcia et al., 2003) and Rhizoctonia solani (Ritchie et al., 2006). Most agricultural soils have water potentials greater than the permanent wilting point of higher plants $(1.5 \mathrm{MPa})$ that are mesophytes. Thus, with solute potential threshold of $6.62 \mathrm{MPa}$ that inhibited the growth of mycelia and sclerotia in this study, S. sclerotiorum is probably adapted to water potentials beyond the threshold of most its hosts. It is therefore, not surprising that $S$. sclerotiorum is quite ubiquitous and also has a host range of over 400 plants.

The results also showed that with increasing salinity the sclerotia developed an electron dense layer of granules or compact melanized cell walls in 6 days instead of 8 days.
Melanized cell walls offer a form of protection to cells beneath the rind cells (Bell and Wheeler, 1986). Thus, the melanization of the sclerotia in essence could make the destruction of sclerotia more difficult. The thick and compact melanized of the rind cell appeared to enhance the survival of the sclerotia.

The effect of the interaction of salinity, temperature, and carbon source showed the production of sclerotia was highly significant (Table 5). The highest numbers of sclerotia were produced at temperatures ranging from 20 to $25^{\circ} \mathrm{C}$ and salinity at 1 to $6 \% \mathrm{NaCl}$ on MEA. This is significant because $S$. sclerotiorum can cause infection on over 400 plants (i.e., variable carbon source) over a wide range of environmental factors. The interaction of these three factors may increase the number of sclerotia produced in some crops or plants, thus increasing myceliogenic or carpogenic infection.

The reports of Abawi and Grogan (1975), Coley-Smith and Cooke (1971) indicated that temperature exerted the most significant influence on apothecial development. Abawi and Grogan (1979) also emphasized moisture as having an obvious effect on mycelium development. The observations of this study indicate that salinity (solute potential), temperature, and carbon source are factors that could either alone or interact to influence the mycelial growth, the development and viability of sclerotia. Thus, for the effective management of diseases caused by $S$. sclerotiorum under semi-arid conditions with salinity and high temperature problems, a number of control strategies including cultural practices, biological control, solarization, chemical, etc need to be integrated. This would reduce the number of sclerotia that could develop apothecia which generate the primary source of inoculum. The results indicated that in the agricultural areas of Kuwait where the soils are rapidly becoming very saline through the use of brackish water coupled with very hot summer temperatures would probably reduce the disease incidence of $S$. sclerotiorum.

\section{Acknowledgements}

The authors wish to thank the College of Graduate studies and Research Administration, Kuwait University for funding this project under YS07/04. Also our thanks go to the Electron Microscopy Unit (EMU) and the Science Analytical Facilities (SAF), Kuwait University, for their assistance in carrying out the project.

\section{References}

Abawi, G. S. and Grogan, R. G. 1979. Epidemiology of disease caused by Sclerotinia species. Phytopathology 69:899-904. Abawi, G. S. and Grogan, R. G. 1975. Source of primary inoculum 
and effects of temperature and moisture on infection of beans by Whetzelinia sclerotiorum. Phytopathology 65:300-309.

Adams, P. B. and Ayers, W. A. 1979. Ecology of Sclerotinia species. Phytopathology 69:896-899.

Agrios, G. N. 1997. Plant Pathology (4 ${ }^{\text {th }}$ ed.), Academic Press. USA.

Bell, A. A. and Wheeler, M. H. 1986. Biosynthesis and functions of fungal melanin. Ann. Rev. Phytopathol. 24:411-451.

Campbell, R. 1989. Biological Control of Microbial Plant. Cambridge University Press. U.K.

Cervantes-Garcia, D., Padilla-Ramirez, J. S., Simpson, J. and Mayek-Perez, N. 2003. Osmotic potential effects on in vitro growth, morphology and pathogenicity of Macrophomina phaseolina. J. Phytopathol. 151:456-462.

Hao, J. J., Subbarao, K. V. and Duniway, J. M. 2003. Germination of Sclerotinia minor and S. sclerotiorum sclerotia under various soil moisture and temperature combinations. Phytopathology $93: 443-450$.

Huang, H. C. 1985. Factors affecting myceliogenic germination of sclerotia of Sclerotinia sclerotiorum. Phytopathology 75: 433-437.

Huang, H. C. 1983. Histology, amino acid leakage, and chemical composition of normal and abnormal sclerotia of Sclerotinia sclerotiorum. Can. J. Bot. 61:1443-1447.
Lumsden, R. D. 1979. Histology and physiology of pathogenesis in plant diseases caused by Sclerotinia species. Phytopathology 69:890-895.

Purdy, L. H. 1979. Sclerotinia sclerotiorum: History, diseases and symptomatology, host range, geographic distribution and impact. Phytopathology 69:875-880.

Purdy, L. H. and Grogan, R. G. 1954. Physiological studies of Sclerotinia sclerotiorum in liquid and agar culture. Phytopathology 44:36-38.

Ritchie, F., McQuilken, M. and Bain, R. 2006. Effect of water potential on mycelial growth, sclerotial production, and germination of Rhizoctonia solani from potato. Mycol. Res. 110:725-733.

Schwartz, H. F. and Steadman, J. R. 1978. Factors affecting sclerotium populations of, and Apothecium production by, Sclerotinia sclerotiorum. Phytopathol. 68:383-388.

Sun, P. and Yang, X. B. 2000. Light, temperature, and moisture effects on apothecium production of Sclerotinia sclerotiorum. Plant Dis. 84:1287-1293.

Tourneau, D. L. 1979. Morphology, Cytology, and physiology of Sclerotinia species in culture. Phytopathology 69:887-890.

Willetts, H. J. and Wong, A. L. 1971. Ontogenetic diversity of sclerotia of Sclerotinia sclerotiorum and related species. Trans. Br. Mycol. Soc. 57:515-524. 